\title{
Analysis of Literacy Skills for Children Aged 5-6 Years through Online Learning in TK Negeri Pembina 1 Medan
}

\author{
Rusmaliyah $^{1}$, Asih Menanti ${ }^{2}$, Aman Simare-mare ${ }^{3}$ \\ ${ }^{1}$ Master Student in Universitas Negeri Medan, Indonesia \\ ${ }^{2,3}$ Universitas Negeri Medan, Indonesia \\ rusmaliyah16@gmail.com
}

\begin{abstract}
This study aims to analyze and describes how the literacy skills of children in TK Negeri 1 Pembina Medan in class B at the age of 5-6 years through online learning during the current pandemic. This research is a type of qualitative descriptive research, with the research subjects namely. The school principal, teachers, school committee, and several children at TK Negeri Pembina 1 Medan. The data collection techniques used were; observation, interview, and documentation. The data analysis used is in the form of descriptive analysis, which includes three lines, namely; data reduction, data presentation, and drawing conclusions. The conclusion obtained is that from the observation sheet of literacy skills in listening, it can be seen that the average listening skill of children is in the developing category as expected (BSH). Speaking ability is in the developing category according to expectations $(B S H)$, while writing ability is in the developing category as expected(BSH), and reading ability is in the developing category $(M B)$.
\end{abstract}

Keywords

literacy; online learning; children aged 5-6 years

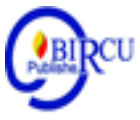

\section{Introduction}

In general, literacy which is taken from English, namely literacy can be defined as the ability to read and write and competence or knowledge in a specified area. In particular, Romdhoni (2013: 90) states that literacy is a social activity that involves certain skills, which are needed to convey, obtain, and interpret information in written form. Meanwhile, Sari and Pujiono (2017: 106) state that literacy skills are the language skills of a person which includes listening, speaking, reading and writing skills which are used to communicate in different ways according to their objectives.

The reality in the learning process especially in terms of literacy skills related to listening, speaking, reading and writingstill centered on the teacher (teacher center). Listening problems include several things, including; children are less able to direct their eyes to the teacher even though only in a few minutes, the child is less able to appreciate the conversations of other people, both teachers and people around them, when the teacher gives instructions the child does not show facial expressions as they should, and the child is less able to follow the storyline conveyed by the teacher because when asked by the teacher a child did not respond.

Problems in speaking also include several things, including; children are less able to answer questions posed by the teacher clearly, children are less able to say words and letters that have the same prefix, children are less able to communicate verbally, children 
are also less able to recognize symbols in various activities during the learning process, and children has not been able to retell the story he heard from the teacher.

Problems in reading found in the field include several things, including; children are less able to distinguish letters both vowels and consonants, children are less able to pronounce objects or words with the same initial sound, and children are less able to connect words with pictures.

Problems in writing found in the field include several things, including; The child is less able to recognize letters correctly, the child is not able to hold the writing tool correctly so that using writing tool for stiff strokes, the child is not able to imitate letters given by the teacher, and the child is not able to make various formations of their own lines. The choice of learning activities determined by the teacher can also cause some children to feel bored, so that children choose to be silent, passive or play with friends who are nearby and make a fuss, so that the atmosphere becomes difficult to control and causes an environment that is not conducive.

These problems must be overcome, because if these problems are ignored, it is very difficult for a student to have skills that are useful for his own life. And if these problems are allowed to be sustainable, human resources that will compete with the global world will not be formed. Competent teachers are teachers who are able to understand the needs of their students and also be able to keep up with the times.

In the problems that exist in parts of the world starting in early 2020, which occurred due to the Covid-19 disease, it has an impact on all areas of human life. One of them has an impact in the field of education starting from the level of PAUD / Kindergarten to Higher Education. This incident requires the teacher to be extra creative, because the children are not learning in the classroom (temporarily according to government directions) but learning is done by the children in their respective homes. Therefore, teachers need to design in such a way that the maximum learning and can help children even without having to meet face to face. Learning with online media (online media) which of course utilizes advanced technology, call it the androit cellphone to the internet being warmly discussed and used in carrying out the learning process that occurs without face to face. Online media is of course very helpful for teachers in conveying learning messages through the help of parents, so that good communication is created between the school and also parents in helping students have literacy skills from an early age.

Online or online learning which is often referred to as e-learning is one of the learning media included in the classification of audio-visual media, because it involves the senses of hearing and the sense of sight. E-learning itself was introduced by Illinois University at Urbana Champaign using a computer-based instruction system. Since then the development of e-learning has developed rapidly in line with advances in science and technology in the world. Effendi, Empy, Hartono, and Zuang (2005: 6) state that e-learning is all activities that use the internet and computer media. Similar to this statement, Sa'ud (2010: 180) states that e-learning is a learning activity via the internet or the use of various technologies.

In order to improve children's literacy skills, learning activities in early childhood aged 5-6 years need to be planned, prepared and implemented with an approach that is in accordance with the development of the early childhood mindset and developed creatively while still paying attention to the characteristics of the child and the child's educational environment. This is because the role of educators and the approach used in early childhood education is very important in developing the potential of children aged 5-6. To instill literacy in early childhood education, it is necessary to develop an ideal learning 
approach according to the developmental needs and interests of each child, and to be able to take advantage of his special curiosity in online learning.

Based on the above arguments. So this study aims to describe the literacy skills of children aged 5-6 years in online learning. The results of this analysis will be useful for teachers and education policy-making officials to package curricula and online learning models that are in accordance with the characteristics of early childhood and at the same time be able to improve children's literacy skills during the pandemic.

\section{Review of Literatures}

\subsection{Definition of Ability}

Soelaiman (2007: 112) states Ability is a trait that is inherited from birth or indeed that is learned by someone so that it allows a person to complete his work, both mentally and physically. Meanwhile, Stephen P. Robins (2006: 46) states that the ability or what is called the ability is the individual's capacity to carry out various tasks in certain jobs. Another opinion by Kreitner and Kinicki (2005: 185) states that ability is a stable characteristic that is closely related to a person's physical and mental health.

Based on some of the opinions above, it can be concluded that the ability (ability) is an intelligence in someone who has been inherent from birth or even learned so that it is obtained through a process of experience which can ultimately complete a particular task at hand, including both mental and physical.

\subsection{Definition of Literacy}

Literacy is one of the abilities that is being discussed in the era of the industrial revolution 4.0. According to Pratiwi and Asyarotin (2019: 68), literacy is a basic ability possessed by a person with regard to reading, counting, and writing. Meanwhile, according to Alberta (2009: 6) literacy is an ability that is more than just reading and writing, which involves knowledge, skills and competencies that enable individuals to think critically. In line with this opinion, Musthafa (2014: 7) states that literacy is the ability to read, write and think critically. Through literacy, it is hoped that critical awareness will grow to learn something new or to assimilate it with previous knowledge.

Based on some of the opinions above, it can be concluded that literacy is a basic ability possessed by someone which includes listening, speaking, reading, and writing as a basis for developing effective and productive learning so as to enable children to be skilled at finding and processing information.

\subsection{Characteristics of Early Childhood (5-6 Years)}

Early childhood is in the golden phase, which is the most important and fundamental initial period throughout the growth and development of human life. If the various potentials of this golden age are not well stimulated, it will hamper the next stage of child development. This golden age is also only once and cannot be repeated so that early childhood is at a critical age.

From the description above, the authors conclude that early childhood literacy is language skills related to reading, writing, listening and speaking. The four forms of language can be classified into spoken and written language, or they can also be classified into receptive and expressive language. The spoken language is listening and speaking, the written language is reading and writing. 
According to the Regulation of the Minister of Education and Culture of the Republic of Indonesia Number 146 of 2014 concerning the 2013 Curriculum, the language skills of children aged 5-6 years are as follows:

1. In children aged 5-6 years, the development of children's language skills is characterized by the following abilities:

a. Retelling what was heard with more vocabulary

b. Express desires, feelings, and opinions in simple sentences in communicating with children or adults

c. Shows happy behavior to read known books

d. Express the feeling of the idea with the appropriate choice of words when communicating

e. Retelling simple story content

f. Shows the form of symbols (pre writing)

g. Make a picture with some scribbles / writing that is already in the form of letters / words, writing the letters of his own name.

In addition, the characteristics of early childhood are also differentiated into the stages of their developmental aspects which include; physical-motor development, cognitive development, socio-emotional development, and language development.

\subsection{Definition of Online Learning}

In Wikipedia.com, online learning or often called electronic learning (e-learning) is a part of distance education that specifically combines electronic technology and internetbased technology. This distance education is so appropriate to use in 2020 considering the implementation of learning carried out in their respective homes due to the Covid-19 pandemic that shook the world. Thus online learning is very helpful for teachers in delivering learning material to students.

According to Hanum (2013: 92) states e-learningis a form of information technology applied in the field of education in the form of cyberspace. Meanwhile, Karwati (2014: 44) states that e-learning is an instructional or learning process that involves the use of electronic equipment to create, foster, convey, assess and facilitate the interactive teaching and learning process wherever and whenever.

Meanwhile, according to Sari (2015: 25) states that e-learning is learning that uses sophisticated ICT facilities that make it easy for users to learn independently, anywhere, anytime, thus encouraging them to enjoy learning and trying to improve their learning competence. In line with this statement Abdulmajid, Pramuntadi, Riyanto, and Rocmah (2017: 171) state that e-learning is a tool in learning and training that uses internet connections and web-based interactions.

Distance learning is also still less effective than face-to-face learning. This is due to students who study exact sciences will find it difficult to understand the exact sciences concepts properly so that it becomes a challenge for students who study these sciences especially in the fields of biology, chemistry, physics, and mathematics (Dewi in Wahid, 2020) .

Based on some of the opinions above, it can be concluded that online learning or called e-learning is a teacher's effort to include students in making it easier to achieve certain learning goals remotely using technological sophistication.

\subsection{Benefits of Online Learning}

According to Alimuddin, Rahamma, and Nadjib (2015: 388), the benefits of online learning (e-learning) are to shorten learning time and facilitate interaction between 
teachers and students. The ability to understand is very fundamental, because understanding will be able to achieve procedural knowledge (Adliani, 2020). Meanwhile, Rismiati, Rita, and Rahmasari (2013: 69) stated the benefits of e-learning, including:

1) Learners can access knowledge at any time unlimited time and place.

2) Students can establish communication via the internet so that more knowledge they can get.

3) Learners learn easier and more fun.

4) Through e-learning, the learning process is more interactive and innovative, and $d$. Through e-learning, students are encouraged to explore through the available webside, so that their creativity and curiosity continue to grow.

Based on the above statement, it can be concluded that learning e-learning very helpful in the learning process because it has benefits that are not only useful for students but also for teachers.

\section{Research Method}

Sugiharto (2020) stated that low quality of education in Indonesia indicates that it needs a serious effort from all parties to improve the quality of education in Indonesia. The approach used in this study is a qualitative approach which aims to obtain knowledge that can be used in describing a symptom or phenomenon that occurs in the field. The research location in TK Negeri Pembina 1 Medan as a sampling place for online learning is located on Jl. Karya Ujung Helvetia Medan District which will be carried out in the odd semester of the 2020-2021 school year.The subjects in this study were the principal, teachers and children in TK Negeri Medan. The number of children in Pembina 1 Medan Kindergarten in Group B Mawar was 15 children. The children of group B Mawar are sample trials taken by total sampling with varying abilities, gender and intelligence levels to be taught. The object of this research is the analysis of children's literacy skills using online learning at TK Pembina Negeri 1 Medan. The primary data sources in this study were the principal; teacher council and administrative staff; There are 15 children in the class in group B Mawar. Secondary data in this study are documents related to the problem being researched such as: profile documents of the TK Negeri 1 Medan Kindergarten School and documents related to children's literacy skills such as reading, writing, speaking and listening during the learning process. Several techniquescollectionThe data used in this qualitative research are observation, interviews, and documentation. Data analysis from the results of this study was carried out based on descriptive analysis. The analysis consists of three interacting analysis lines, namely data reduction, data presentation and conclusion drawing. StrengthenvalidityData on the findings and authenticity of the research, the researcher refers to the use of data validity standards consisting of; credibility, transferability, dependability, and confirmation.

\section{Discussion}

\subsection{Description of Initial Observations}

The first step that the researcher took before carrying out the research was making initial observations in the form of pre-action activities without disturbing learning to find out the initial state of children's literacy development by observing through direct children's learning records. In addition to conducting observations, researchers also conducted interviews with class teachers about activities carried out by children in learning activities during Covid. 
While observing the video of the assignments given by the child to the class teacher, it was seen that the children studied enthusiastically even though they were a little lazy because they did not meet their friends at school and also couldn't play, besides that parents who help children learn must be more patient because during This is the teacher who always teaches the children in school.

In the video, it can be seen that the children answer and do the assignments given by the teacher even though they are assisted by their respective parents. Following are the results of interviews with class teacher Siti Khadijah about the learning process during Covid:

"Learning during the Covid pandemic takes place online or remotely through Whatsaap (WA) and other communication tools. During online learning I always give assignments from WA, starting from greeting the children to sending assignments that I give through learning videos in the WA group, and asking parents for help to record children's activities at home and then sending assignments through the Whatsaap group".

From the interview with the teacher, it seems that the teacher must be ready to follow developments and must be ready with all activities using social media. Don't let the teacher get confused and look tech-savvy compared to their own children.

The following is an interview with Siti Khadijah's class teacher about children's activities during learning and literacy:

"When I give assignments, parents of children must be ready to record videos of their children while studying and send them to me immediately so that I can give grades and keep abreast of the child's development ".

\subsection{Description of Children's Literacy Skills}

\section{a. Listening Ability}

Table 1. Listening Skills Observation Sheet Recapitulation

\begin{tabular}{|c|c|c|c|c|c|}
\hline No. & INDICATOR & BB & MB & $\mathrm{BSH}$ & BSB \\
\hline 1 & $\begin{array}{l}\text { The child is able to direct his gaze to the teacher } \\
\text { for several minutes }\end{array}$ & - & 1 & 12 & 2 \\
\hline 2 & $\begin{array}{l}\text { Children are able to appreciate other people's } \\
\text { conversations }\end{array}$ & - & 1 & 13 & 1 \\
\hline 3 & $\begin{array}{l}\text { Children are able to show facial expressions } \\
\text { according to teacher instructions }\end{array}$ & - & 1 & 14 & - \\
\hline 4 & Children are able to name characters in the story & 1 & 11 & 3 & 1 \\
\hline 5 & $\begin{array}{l}\text { Children are able to show pictures according to } \\
\text { teacher instructions }\end{array}$ & - & 2 & 13 & - \\
\hline 6 & $\begin{array}{l}\text { Children are able to mention the characteristics of } \\
\text { the characters in the stories they hear }\end{array}$ & 1 & 10 & 4 & - \\
\hline \multicolumn{2}{|r|}{ Total } & $\mathbf{1}$ & 26 & 59 & 4 \\
\hline
\end{tabular}

Information :

BB ; Not developed (if the child is asked to be guided by or exemplified by the teacher)

MB ; Starting to develop (if the child is asked to still have to be approved or assisted by the teacher) 
BSH ; Develop according to expectations (if children can do it independently and consistently without having to deal with or be exemplified by the teacher)

BSB; Very well developed (if the child is able to use independently and is able to help those who have not met the requirements as expected).

From the literacy observation sheet about listening, it can be concluded that the average listening skill of children is in the developing category as expected (BSH). Where it can be seen from the six indicators, the BSH category occupies the highest number.

\section{b. Speaking Ability}

Table 2. Recapitulation of Speaking Skills Observation Sheet

\begin{tabular}{|c|c|c|c|c|c|c|}
\hline $\begin{array}{l}\text { No } \\
\text {. }\end{array}$ & Indicator & Description & BB & MB & BSH & BSB \\
\hline 1 & $\begin{array}{l}\text { Answer } \quad \text { more } \\
\text { complex questions }\end{array}$ & $\begin{array}{l}\text { - Children can answer } \\
\text { according to the questions } \\
\text { given }\end{array}$ & 2 & 6 & 6 & - \\
\hline 2 & $\begin{array}{l}\text { Mention groups of } \\
\text { pictures that have } \\
\text { the same sound }\end{array}$ & $\begin{array}{l}\text { - Children can say } 1 \text { or } \\
\text { more nouns that have the } \\
\text { same initial sound / letter. }\end{array}$ & 2 & 7 & 5 & 1 \\
\hline 3 & $\begin{array}{lr}\text { Communicate } & \\
\text { orally, } & \text { have } \\
\text { vocabulary } & \text { and } \\
\text { recognize } & \text { symbols } \\
\text { for reading / writing } \\
\text { / } \quad \text { counting } \\
\text { preparation }\end{array}$ & $\begin{array}{l}\text { - Children can say the } \\
\text { sound of the initial letters } \\
\text { of the names of objects } \\
\text { around them. } \\
\text { - Children can recognize } \\
\text { vowels and numbers } 1-10 \text {. }\end{array}$ & 2 & 5 & 9 & - \\
\hline 4 & $\begin{array}{l}\text { Continuing some of } \\
\text { the stories / fairy } \\
\text { tales that have been } \\
\text { heard }\end{array}$ & $\begin{array}{l}\text { - Children can retell some } \\
\text { of the stories / tales that } \\
\text { have been heard. }\end{array}$ & 3 & 7 & 6 & - \\
\hline \multicolumn{3}{|c|}{$\begin{array}{lc}\text { Total } \\
\end{array}$} & 9 & 25 & 27 & 2 \\
\hline
\end{tabular}

Information:

BB ; Not yet developed (if the child is asked to be guided by or exemplified by the teacher)

MB ; Starting to develop (if the child is asked to still have to be approved or assisted by the teacher)

BSH ; Develop according to expectations (if children can do it independently and consistently without having to deal with or be exemplified by the teacher)

BSB ; Very well developed (if the child is able to use independently and is able to help those who have not met the requirements as expected).

From the observation sheet of literacy literacy about speaking, it can be concluded that the average speaking skill of children is in the developing category according to expectations (BSH). Where it can be seen from the four indicators, the BSH category occupies the highest number. 


\section{c. Reading Skills}

Table 3. Recapitulation of Reading Skills Observation Sheet

\begin{tabular}{|c|c|c|c|c|c|c|}
\hline No. & Indicator & Description & $\mathbf{B B}$ & MB & BSH & BSB \\
\hline 1 & $\begin{array}{l}\text { Ability to } \\
\text { distinguish } \\
\text { letters }\end{array}$ & $\begin{array}{l}\text { - Able to distinguish vowels } \\
\text { and consonants. } \\
\text { - Compose words correctly and } \\
\text { correctly }\end{array}$ & 1 & 9 & 4 & - \\
\hline 2 & $\begin{array}{l}\text { Ability to } \\
\text { pronounce } \\
\text { objects or words } \\
\text { with the same } \\
\text { initial sound }\end{array}$ & $\begin{array}{l}\text { - Be able to pronounce objects } \\
\text { or words with the same sound } \\
\text { as the initial letters. }\end{array}$ & 1 & 9 & 4 & - \\
\hline 3 & $\begin{array}{l}\text { Ability to link } \\
\text { pictures or } \\
\text { words with } \\
\text { words }\end{array}$ & $\begin{array}{l}\text { - Able to relate pictures that } \\
\text { have been given by the } \\
\text { teacher with simple thoughts. } \\
\text { - Be able to connect words into } \\
\text { easy-to-understand meanings }\end{array}$ & 1 & 6 & 8 & - \\
\hline \multicolumn{3}{|r|}{ Total } & 3 & 24 & 16 & - \\
\hline
\end{tabular}

\section{Information :}

BB; Not yet developed (if the child is asked to be guided by or exemplified by the teacher) $\mathrm{MB}$; Starting to develop (if the child is asked to still have to be approved or assisted by the teacher)

BSH; Develop according to expectations (if children can do it independently and consistently without having to deal with or be exemplified by the teacher)

BSB; Very well developed (if the child is able to use independently and is able to help those who have not met the requirements as expected).

From the observation sheet of literacy literacy about reading, it can be concluded that the average reading skills of children are in the developing category (MB). Where it can be seen from the three indicators of the MB category occupy the highest number.

\section{d. Writing Skills}

Table 4. Recapitulation of Writing Skills Observation Sheet

\begin{tabular}{|l|l|l|l|l|l|c|}
\hline No. & Indicator & Description & BB & MB & BSH & BSB \\
\hline 1 & $\begin{array}{l}\text { Recognizes } \\
\text { letters }\end{array}$ & $\begin{array}{l}\text { - Can say letter symbols } \\
\text { - Do a job well }\end{array}$ & - & 5 & 5 & 5 \\
\hline 2 & $\begin{array}{l}\text { Holds } \\
\text { stationery } \\
\text { properly }\end{array}$ & $\begin{array}{l}\text { - Can hold stationery properly } \\
\text { - Can use stationery to make } \\
\text { scribbles } \\
\text { - Produce special work }\end{array}$ & - & 3 & 10 & 3 \\
\hline 3 & $\begin{array}{l}\text { Mimicking } \\
\text { making letters }\end{array}$ & $\begin{array}{l}\text { Make letters according to the } \\
\text { image shown } \\
\text { Come up with new ideas } \\
\text { Make letters according to your } \\
\text { own creativity }\end{array}$ & 1 & 4 & 8 & 2 \\
\hline
\end{tabular}




\begin{tabular}{|l|l|l|l|l|l|c|}
\hline No. & Indicator & Description & BB & MB & BSH & BSB \\
\hline 4 & $\begin{array}{l}\text { Make various } \\
\text { line shapes } \\
\text { yourself }\end{array}$ & $\begin{array}{l}\text { Make various line shapes } \\
\text { properly according to the } \\
\text { existing examples } \\
\text { Make various line shapes } \\
\text { without being exemplified by } \\
\text { the teacher } \\
\text { Initiative }\end{array}$ & 1 & 3 & 10 & 2 \\
\hline & Total & $\mathbf{2}$ & $\mathbf{1 5}$ & $\mathbf{3 3}$ & $\mathbf{1 2}$ \\
\hline
\end{tabular}

Information :

BB; Not yet developed (if the child is asked to be guided by or exemplified by the teacher) MB; Starting to develop (if the child is asked to still have to be approved or assisted by the teacher)

BSH; Develop according to expectations (if children can do it independently and consistently without having to deal with or be exemplified by the teacher)

BSB; Very well developed (if the child is able to use independently and is able to help those who have not met the requirements as expected).

From the observation sheet of literacy literacy about writing, it can be concluded that the average writing skill of children is in the category of developing according to expectations $(\mathrm{BSH})$. Where it can be seen from the three indicators, the BSH category occupies the highest number.

\subsection{Strategies and Literacy Skills in Online Learning}

In collecting data through observation sheets, interviews and documentation were carried out for one month. The student learning process is carried out online as well as a collection of assignments, where the parents of students 1856ndica go to school and collect their children's assignments. The learning theme in this research is "Lingkunganku". In one theme there are 3 sub-themes, namely the sub-theme "my house" which is held on August 24, 2020 for one week. The sub-theme "my school" was held on August 31, 2020 for one week, and the sub-theme "healthy food and drink" was held on September 7, 2020 for one week. In one sub-theme spent one week meeting. Where in the online learning process at TK Negeri Pembina 1 Medan the teacher gives assignments and explains learning through the WA group. Then the students completed the assignment in one week and gathered them to school. And so on until the sub-theme has been studied.

In observing students about their literacy skills such as reading, writing, speaking and listening, they are carried out separately from the learning process. After learning activities and all assignments such as student activity videos have been collected, then observations are made with the observation sheet. The following is the data collection strategy through observations made:

\section{a. Listening Ability}

The first literacy activity was listening which was observed on Monday, September 14 2020. From the results of the observation sheet through assignments and videos of the online learning process for 3 weeks on my environmental theme, it was found that the online learning process was said to be good. As usual, it begins with the opening activity, the children pray and sing recorded by each parent, then the teacher explains the day's activities and distributes a learning video in the form of a story about a little tiger as 
material for listening activities and asking questions about the contents of the story. Then when students are listening to the story, parents are asked to record their listening activities and send the results of their children's activities back to the class.

The activity of children watching learning videos is one of the teacher's strategies to determine children's literacy skills. At the beginning of the activity, it was seen that the video recording of the children was listening well, but the longer some children were not focused and even looked sleepy. From the literacy literacy observation sheet about listening, it can be seen that the average listening skill of children is in the developing category as expected (BSH). Where is seen from the sixth1857ndicator, the category developing according to expectations $(\mathrm{BSH})$ occupies the highest number. Most of the 15 children are able to name the characters in the story and can name the character traits. As in the video recording sent to the teacher, the results of the children's assignments can retell the stories they have heard using their own language. Even though there is one child, namely a child with code 15 who is still in the underdeveloped category, because the child is still greatly assisted by their parents in completing their tasks. After the video was finished, many children had already watched it1857ndi answers the questions given from the contents of the story. In addition, there are 14 children who are able to show facial expressions according to the teacher's instructions and are1857the highest indicator which is 1857 ndicator where the child has developed as expected. Of the 15 children only 4 were already very well developed in some1857ndicator. It can be seen that in listening activities at TK Negeri 1 Pembina, 15 children on average develop according to expectations.

\section{b. Speaking Ability}

Through observations carried out on Tuesday, September 15, 2020, of all the videos and assignments that had been submitted for three weeks with the theme of my environment, it was seen that online activities as usual began with opening activities, children praying and singing as usual then recorded by each each parent, then the teacher explains the activities of the day on the learning videos sent through the class whatsaap group, namely speaking literacy activities. In speaking activities, the child is asked to answer the question of the parent, the stranger, then the parents of the child record the results of their introduction. After that, parents are asked to give questions from the teacher about the little tiger fairy tale that the child must answer.

The activity of children introducing themselves and answering questions in front of the camera is one of the teachers' strategies to determine children's literacy skills. From the observation sheet of literacy skills about speaking, it can be seen that on average children speaking skills are in the developing category as expected (BSH). Where is seen from the fourth1857ndicator, the BSH category occupies the highest number. From the children's ability to speak, it can be seen that the children speak confidently and speak according to their respective abilities, there are 3 children who cannot answer according to the questions given. Children with codes 06, 09 and 15 are children who cannot speak fluently and have a lack of vocabulary so that their parents still help their parents to talk and answer questions. Of the 15 children, only 9 children can communicate verbally, have vocabulary and are familiar1857ndica-symbols in reading preparation. In speaking skills, there are only 2 children who have developed very well in TK Negeri 1 Pembina Medan.

\section{c. Reading Ability}

The third literacy activity is reading which is observed on Wednesday, September 16, 2020 with the theme of my environment through assignments and videos of the learning process submitted to school. In online activities as usual, starting with the opening activity, 
the children pray and sing as usual, then recorded by each parent, then the teacher explains today's activities through the class group whatsaap, namely speaking literacy activities. In reading / spelling activities for TK Negeri 1 Pembina Medan children, children are asked to compile "letter cards" until they are compiled into the words "Little Tiger" and "house". Then the children were asked to spell it. As usual in online learning, parents are required to record and send children's activities as a result of children's assignments.

The activity of children arranging letters and spelling them in front of the camera is one of the teacher's strategies to find out children's literacy skills. From the observation sheet of literacy literacy about reading, it can be seen that the average reading skills of children are in the developing category (MB). Where is seen from the third1858ndicator, the MB category occupies the highest number.

In reading activities, the children are seen to be very enthusiastic in compiling letter cards to form the word "house" or the word "little tiger". If the child succeeds in compiling and reading words from the letter arrangement, the parents will give praise and they will cheer "hooray" as an appreciation for their success, from the three1858There are still many children who have not been able to connect words into easy-to-understand meanings, only some children are able to do it, besides that, children are also not able and have not developed in arranging letters into words correctly. So it can be concluded that the children's reading activities are still developing (MB). Of the 15 children there were 2 children who had not developed in reading skills, namely children with code 01 and 10 where they could not distinguish letters and could not say words with the same initial sound.

\section{d. Writing Skills}

The fourth literacy activity is writing activities that are observed on Thursday, 17 September 2020 with the theme of my environment with 3 sub-themes seen from the video and assignments that have been submitted to school. In online activities as usual, starting with the opening of the children praying and singing as usual then recorded by each parent, then the teacher explained today's activities through the class whatsaap group, namely writing literacy activities. In writing activities, TK Negeri 1 Pembina Medan children were asked to draw and color the picture first. After that the children were asked to write the little tiger $\mathrm{d}$ on the picture correctly. As usual, parents are required to record children's activities making pictures and writing, then send it to the class teacher Ibu Siti Khadijah.

The activity of children writing on pictures that they make themselves and working on them in front of the camera is one of the teachers' strategies to find out children's literacy skills. From the observation sheet of literacy literacy about writing, it can be seen that the average writing skills of children are in the developing category as expected (BSH). Where is seen from the third1858ndicator, the BSH category occupies the highest number.

In this writing activity it is combined with the activity of drawing clouds by the children so that they are excited to learn and write. The indicator for the average child in the category has developed as expected. It can be seen that of the 15 children, they are able to hold the stationery correctly, are able to recognize letters and can make various shapes of their own lines. So that in the ability to speak, the TK Negeri 1 Pembina children have developed as expected. 


\section{Conclusion}

1. From the literacy literacy observation sheet about listening, it can be seen that the average listening skill of children is in the developing category as expected (BSH). Where it can be seen from the six indicators, the category developing according to expectations $(\mathrm{BSH})$ occupies the highest number.

2. From the observation sheet of literacy literacy about speaking, it can be seen that the average speaking skill of children is in the developing category as expected (BSH). Where it can be seen from the four indicators, the BSH category occupies the highest number.

3. From the observation sheet on literacy literacy, it can be seen that the average writing skill of children is in the developing category (MB). As seen from the three indicators, the MB category occupies the highest number.

4. From the observation sheet of literacy literacy about reading, it can be seen that the average reading skills of children are in the developing category according to expectations (BSH). Where it can be seen from the three indicators, the BSH category occupies the highest number.

\section{References}

Abdulmajid, Pramuntadi, and Rochmah. (2017). Penerapan E-Learning Sebagai Pendukung Adaptive Learning dan Peningkatan Kompetensi Anak SMK di Kabupaten Bantul. Jurnal Taman Vokasi, 5 (2).

Adliani, S., Asmin, and Hasratuddin. (2020). The Influence of Realistic Mathematical Approach to Understanding Concept and the Mathematical Connection Ability of Islamic Private Vocational School Students Hikmatul Fadhillah Medan Class VII. Budapest International Research and Critics in Linguistics and Education (BirLE) Journal Vol 3 (1): 487-499.

Alberta. (2009). Special Education Branch. Guidelines for Practice; Comprehensive School Guidance \& Conselling Programs and Services a Program Development and Validation Cheklist. Canada: Alberta Education.

Alimuddin, Rahamma, and Nadjib. (2015). Intensitas Penggunaan E-Learning dalam Menunjang Pembelajaran Mahaanak Program Sarjana (S1) di Univeristas Hasanuddin. Jurnal Komunikasi KAREBA, 4 (4).

Effendi, Empy, Hartono, and Zuang. (2005). E-learning Konsep dan Aplikasi. Yogyakarta: Andi.

Hanum, N.S. (2013). Keefektifan E-learning sebagai media pembelajaran ( studi evaluasi model pembelajaran E-learning SMK Telkom sandhy putra Purwokerto. Jurnal pendidikan vokasi, 3 (1): 90-102.

Karwati, Euis. (2014). Pengaruh Pembelajaran Elektronik (E-Learning) Terhadap Mutu Belajar Mahaanak. Jurnal Penelitian Komunikasi, 17 (1): 41-54.

Kreitner dan Kinicki. (2005). Perilaku Organisasi. Jakarta: Salemba Empat.

Musthafa, Bachrudin. (2014). Literasi Dini dan Literasi Remaja: Teori, Konsep dan Praktik. Bandung: CREST.

Pratiwi and Asyarotin. (2019). Implementasi literasi budaya dan kewargaan sebagai solusi disinformasi pada generasi millennial di Indonesia. Jurnal Kajian Informasi dan Perpustakaan, 7 (1).

Rismiati, Rita and Rahmasari. (2013). Gartika. E-Learning. Bandung: Yrama Widya.

Romdhoni. (2013). Al-quran dan Literasi. Depok: Literatur Nusantara. 
Sari. Pusvyta. (2015). Memotivasi Belajar dengan Menggunakan E-Leraning. Jurnal Ummul Qura, 4 (2).

Sari dan Pujiono. (2017). Budaya Literasi di Kalangan Mahaanak FBS UNY. Litera, 16 (1).

Sa'ud. (2010). Inovasi pendidikan. Bandung: Alfabeta.

Soelaiman. (2007). Sumber Belajar dan Alat Permainan. Jakarta: Grasindo.

Sugiharto (2020) Geographical students' learning outcomes on basic political science by using cooperative learning model with Group Investigation (GI) type in State University of Medan, Indonesia, Journal of Human Behavior in the Social Environment, 30:4, 447-456, DOI: 10.1080/10911359.2019.1696261.

Wahid, R., Pribadi, F., and Wakas, B.E. (2020). Digital Activism: Covid-19 Effects in Campus Learning. Budapest International Research and Critics in Linguistics and Education (BirLE) Journal Vol 3 (3): 1336-1342. 